\title{
James M. McCaffrey, Going for Broke. Japanese American Soldiers in the War against Nazi Germany, University of Okla- homa Press, Norman, OK 2013, ss. 413.
}

Losy amerykańskich żołnierzy japońskiego pochodzenia podczas drugiej wojny światowej, zwłaszcza tych biorących udział w walkach w Europie - jedynym teatrze wojennym, na którym walczyli oni w odrębnych oddziałach - budziły zainteresowanie historyków niemal od samego początku. Od zakończenia wojny ukazało się co najmniej kilkanaście publikacji przedstawiających wkład Nisei w zwycięstwo nad Niemcami ${ }^{1}$. Temat ten popularny także obecnie, staje się zarazem coraz bardziej znany społeczeństwu amerykańskiemu. Dotyczy to nie tylko dziejów oddziałów wojskowych, ale także historii Japończyków w Stanach Zjednoczonych podczas II wojny światowej. Duża w tym zasługa instytucji tworzonych przez amerykańskich Japończyków, stawiających sobie za cel edukowanie społeczeństwa i kultywowanie pamięci o wojennych dokonaniach ich przodków. Ułatwiają one także pracę historykom, tworząc ogólnodostępne internetowe archiwa, zawierające tysiące dokumentów, zdjęć, artykułów prasowych, wspomnień żołnierzy, czy przeprowadzonych z nimi wywiadów. Należy w tym kontekście wymienić zwłaszcza dwie instytucje. Pierwszą jest Go For Broke National Education Center, udostępniający największy zbiór wywiadów z Nisei, liczący ponad 700 filmów². Inną instytucją, udostępniającą nie tylko wywiady z weteranami, ale także materiały dotyczące internowania Japończyków, jest Densho: Japanese American Legacy Project. Internetowe archiwum zawiera ponad 1600 godzin wywiadów z Nisei i ponad 12000 zdjęć, dokumentów i egzemplarzy prasy obozowej ${ }^{3}$. Ciekawym projektem instytucji jest także Densho Encyclopedia, obejmująca kilkaset wyjątkowo profesjonalnie zredagowanych haseł z zakresu wojennej historii Japończyków w Stanach Zjednoczonych ${ }^{4}$. Inne instytucje także dysponują bardzo bogatymi, a zarazem różnorodnymi zbiorami, dostępnymi w Internecie ${ }^{5}$.

1 Jako pierwszy temat poruszył: O. C. Shirey, Americans: The Story of the 442d Combat Team, Washington D.C. 1946. W ostatnich latach opublikowane zostały m.in.: R. Asahina, Just Americans: How Japanese Americans Won a War at Home and Abroad. The Story of the 100th Battalion/442d Regimental Combat Team in World War II, New York 2006; B. Yenne, Rising Sons: The Japanese Americans GIs Who Fought for the United States in World War II, New York 2007. Amerykanie japońskiego pochodzenia mieli swój udział także w zwycięstwie nad Japonią. Na Pacyfiku nie tworzyli jednak odrębnych oddziałów, a głównie pracowali dla wywiadu wojskowego jako tłumacze, zob. J. C. McNaughton, Nisei Linguists: Japanese Americans in the Military Intelligence Service during World War II, Washington D.C. 2006.

2 http://www.goforbroke.org/.

3 http://www.densho.org/archive/default.asp, dostęp do bogatych zbiorów archiwum jest bezpłatny, wymaga jednak wcześniejszej rejestracji.

4 http://encyclopedia.densho.org/.

5 M.in. Japanese American Veterans Association - http://www.javadc.org/, JARDA: Japanese 
Temat udziału Nisei w wojnie toczonej przeciwko III Rzeszy, podjął niedawno także James M. McCaffrey, historyk wojskowości amerykańskiej, autor wielu prac na ten temat ${ }^{6}$. W jego założeniu, o czym wspomina we wstępie, książka ma być syntezą, podsumowaniem dotychczasowego dorobku innych badaczy, ale także, w dużej mierze, opisem losów zwykłych żołnierzy bazującym na ich doświadczeniach (warto odnotować, że jest ona dedykowana jednemu z jej bohaterów, żołnierzowi 442d Regimental Combat Team, sierżantowi Carlowi K. Morita).

Konstrukcja pracy odzwierciedla założenia autora. Przedstawia dzieje oddziałów złożonych z Amerykanów japońskiego pochodzenia od początku ich istnienia aż po koniec wojny. Taki układ ułatwia wprowadzenie w temat nawet mało znającego zagadnienie czytelnika. McCaffrey przedstawił losy nie tylko najbardziej znanych jednostek złożonych z Nisei, czyli 100 Battalion i 442 Regimental Combat Team, ale również tych, którym dotychczas w literaturze poświęcono mniej uwagi jak np. 522 Field Artillery Battalion. Książka posiada solidną bibliografię. Autor wykorzystał wszystkie najważniejsze opracowania i monografie. Zaletą pracy jest wykorzystanie na szeroką skalę materiałów, zwłaszcza wspomnień i wywiadów z żołnierzami, dostępnych w Internecie, zarówno na stronach instytucji wymienionych wcześniej jak i wielu innych. Sposób prowadzenia narracji, umiejscawianie opisu losów Nisei w szerszym kontekście wydarzeń politycznych i działań zbrojnych, znacznie ułatwia lekturę. Dzięki układowi pracy i optymalnemu podziałowi na rozdziały, temat pracy został przedstawiony w sposób kompletny. Pewne mankamenty, choć niewielkie, znaleźć można w dwóch pierwszych rozdziałach. Głównym celem wydaje się przedstawianie genezy podpisania przez prezydenta Executive Order 9066. Autor nie nakreślił, w choćby bardzo skrótowy sposób, burzliwej historii Japończyków w Stanach Zjednoczonych. Miała ona przecież pewien wpływ na postawę społeczeństwa i jego elit, a w konsekwencji, decyzję o internowaniu? ${ }^{7}$ Słabo została scharakteryzowana także sama społeczność Amerykanów japońskiego pochodzenia. Występujące wśród niej podziały nie były bez znaczenia, a ich znajomość pozwoliłaby z innej perspektywy patrzeć na opisywane wydarzenia. Przykładem może tu być przytoczenie, bez odniesienia do tych podziałów, pełnych gniewu i złości reakcji Nisei po japońskim ataku na Pearl Harbor. Była to jednak generacja, do której należało ok. dwóch trzecich całej populacji Amerykanów japońskiego pochodzenia, urodzona i wychowana w Stanach Zjednoczonych i przez to identyfikująca się

American Relocation Digital Archives - http://www.calisphere.universityofcalifornia.edu/jarda/, Japanese American National Museum - http://www.janm.org/.

6 M.in. Army of Manifest Destiny: The American Soldier in the Mexican War, 1846-1848, New York 1992; The Army in Transformation, 1790-1860, Westport, CT 2006; Inside the Spanish-American War: A History Based on First-Person Accounts, Jefferson, N.C. 2009.

7 Zob. G. Robinson, By Order of the President: FDR and the Internment of Japanese Americans, Cambridge - London 2001. 
z tym państwem, a nie z krajem przodków, często znanym wyłącznie z opowieści rodziców. Mniej jednoznaczną postawę wobec wojny przyjmowali Issei, Japończycy pierwszej generacji, będący emigrantami z państwa Cesarza, nie mogącymi zgodnie z ówczesnym prawem uzyskać amerykańskiego obywatelstwa. Część z nich, będąca wprawdzie w zdecydowanej mniejszości, jawnie okazywała swoją sympatię wobec Japonii. Jeden z mieszkańców Hawajów, Japończyk, usłyszał następnego dnia po ataku na Pearl Harbor, w centrum Honolulu, jak jego znajomy rodak z generacji Issei krzyczał do niego komentując: wykonali wspaniała robotę! ${ }^{8}$. Poruszane $\mathrm{w}$ drugim rozdziale kwestie lokalizacji i wyglądu obozów internowania, moim zdaniem, powinny znajdować się w pierwszym rozdziale „Pearl Harbor and after”. Dawałoby to pełniejszy obraz konsekwencji wybuchy wojny, które dotknęły Amerykanów japońskiego pochodzenia. Dużym mankamentem pracy jest brak map. W całej rozprawie, liczącej ponad 400 stron, nie ma ani jednej.

Książka składa się z wprowadzenia, dziewięciu rozdziałów i epilogu. Zawiera ponadto bibliografię i indeks. Na początku pierwszego rozdziału została zarysowana sytuacja międzynarodowa, w jakiej znalazły się Stany Zjednoczone w 1941 r., pogorszenie się stosunków z Niemcami i negocjacje z Japonią. McCaffrey stwierdza w tym miejscu, że 10-punktowa propozycja pokojowa przedstawiona stronie japońskiej 26 listopada, była dla niej nie do przyjęcia i nie pozostawiła innego wyboru jak rozpoczęcie wojny (s. 19). Następnie opisuje atak japoński na Pearl Harbor, głównie z perspektywy Amerykanów japońskiego pochodzenia. Wywołał on u nich bardzo negatywne emocje skierowane przeciwko Japonii. Jeden z Nisei wspominał, że tamtego dnia poczuł mieszaninę szoku, złości, wstydu i smutku oraz głęboka boleść i rozpacz, ponieważ kraj, który został nauczony przez rodziców czcić, rozpoczą wojnę, przeciwko państwu, które kochat. Inny Nisei, mieszkaniec Hawajów, był bardziej dosadny: Jak bardzo nienawidzitem Japońców za to, że sprowadzili to [wojnę] na nas (s. 20-21). Paradoksalnie, w rozpoczętej 7 grudnia wojnie Nisei byli od początku aktywnie obecni. Pierwszy japoński żołnierz wzięty do niewoli, dowódca jednej z pięciu miniaturowych łodzi podwodnych biorących udział w ataku na Pearl Harbor, Kazuo Sakamaki, został pojmany przez sierżanta japońskiego pochodzenia i białego porucznika. Ponadto członkowie United Japanese Society, zgromadzeni w teatrze w Honolulu z okazji wręczenia świadectwa ukończenia kursu medycznego, zostali bezpośrednio po japońskim ataku skierowani do udzielania pomocy poszkodowanym. Po wybuchu wojny Amerykańscy Japończycy stali się ofiarami nagonki, w której wzięli udział liczni politycy, wojskowi i prasa. Jej rezultatem było internowanie Japończyków i ich różnorakie szykanowanie w armii. W styczniu 1942 r. z powodu wątpliwości co do lojalności Nisei została rozwiązana Gwar-

8 F. Odo, No Sword to Bury: Japanese Americans in Hawai'i during World War II, Philadelphia, PA 2004, s. 104. 
dia Terytorialna Hawajów. Część jej żołnierzy, pochodzenia japońskiego wyraziła wówczas gotowość do dalszej służby ojczyźnie. W odpowiedzi władze wojskowe zdecydowały się na utworzenie jednostki, zajmującej się głównie pracami budowlanymi. Jej członkowie określili ją mianem Varsity Victory Volunteers. W maju 1942 r. Nisei zostali usunięci z hawajskiej Gwardii Narodowej i skierowani do nowo utworzonego Hawaiian Provisional Battalion. Jednostka ta została następnie przetransportowana na kontynent i przekształcona w 100 Battalion. Była to pierwsza jednostka wojskowa złożona z Amerykanów japońskiego pochodzenia.

Drugi rozdział opisuje genezę powstania odrębnych oddziałów złożonych z Nisei. Kwestia służby Nisei w armii amerykańskiej, długo pozostawała dyskusyjna. Władze wojskowe i polityczne rozważały, czy korzystniej byłoby przydzielić ich do standardowych jednostek, w których służyli biali Amerykanie, czy też utworzyć dla nich odrębne oddziały. Za pierwszym rozwiązaniem z pewnością przemawiały względy organizacyjne. Pojawiały się jednak opinie, że przydzielanie Japończyków do zwykłych oddziałów wywoła protesty Afroamerykanów, którzy służyli w odrębnych jednostkach, kierowanych przez białych oficerów. Co więcej, część żołnierzy zostałaby przydzielona do dywizji kierowanych na Pacyfik, konieczna byłaby więc ich obecność na Zachodnim Wybrzeżu, na którym zgodnie z ówczesnymi regulacjami Japończykom przebywać nie było wolno. Utworzenie odrębnej jednostki ułatwiłoby także kontrolę nad Nisei, w których uczciwość w dalszym ciągu nie do końca wierzono. Sprzeczne opinie na ten temat pojawiały się także wśród samych Amerykańskich Japończyków. Zdaniem części z nich, służenie w białych oddziałach byłoby potwierdzeniem równości. Inni z kolei uważali, że łatwiej jest dowieść swojej lojalności i uzyskać rozgłos bohaterskimi czynami walcząc w jednostce złożonej wyłącznie z Japończyków (s. 58-59). Dyskusja na ten temat została zakończona decyzją podjętą 1 stycznia 1943 r. przez szefa sztabu gen. Marshalla, zgodnie z którą mieli oni służyć w wydzielonej jednostce, 442 Regimental Combat Team.

Trzeci rozdział skupia się na przygotowaniach nowo powstałej jednostki do czynnego udziału w walce. Była to sprawa o tyle istotna, że tylko nieliczni żołnierze posiadali doświadczenie wojskowe, nabyte podczas służby w Gwardii Terytorialnej Hawajów i Varsity Victory Volunteers. Szkolenie odbywające się w Camp Shelby w stanie Missisipi, było dla żołnierzy 442. pułku, którzy doświadczyli szykan z powodu swojego pochodzenia rasowego i narodowego, okazją do poznania stosunków społecznych panujących na południu państwa. Co zrozumiałe, obserwacje wywoływały nieraz sprzeciw wobec praktyk segregacyjnych, w skrajnych przypadkach sprzeciw ten miał charakter czynny (s. $82 \mathrm{i}$ n.). W pierwszej połowie sierpnia, zakończyło się szkolenie 100 Battalion, następnie jednostka została przetransportowana przez Nowy Jork do Oranu w Algierii, do którego przybyła 2 września.

Rozdział czwarty opisuje udział 100 . batalionu w walkach z Niemcami we Włoszech. Jest on ujęty w szerszej perspektywie. McCaffrey przedstawia różne 
warianty desantu w Europie brane pod uwagę przez Anglosasów. Opisuje przebieg kampanii włoskiej, włączając obalenie rządów Mussoliniego i w rezultacie zmianę sojuszy przez Włochy. Narracja rozdziału kończy się wraz z przejściem 34. dywizji, w skład której wchodził batalion, do rezerw, w miesiąc po zajęciu Rzymu przez siły sprzymierzone. Batalion brał bezpośredni udział w walkach o stolicę Włoch, będąc częścią składową Task Force Singles. 4 czerwca, gdy znajdował się 6 mil od Rzymu, otrzymał rozkaz zatrzymania się, a miasto zostało ostatecznie zajęte przez siły 1. Dywizji Pancernej. Sytuacja ta miała u części żołnierzy wywołać przekonanie, że po raz kolejny padli ofiarą szykany, u której podstaw leżał rasizm (s. 167).

Rozdział piąty jest opisem bezpośrednich przygotowań do przetransportowania 442 RCT do Europy, jak i samej podróży. Autor wskazał na problemy, z jakimi borykała się jednostka. Na pierwszy plan wysuwały się braki kadrowe. Pułk, składający się wyłącznie (poza oficerami) z Amerykanów japońskiego pochodzenia, miał spore problemy z osiągnięciem pełnego stanu etatowego. Pobór mógł dokonywać się tylko spośród liczącej niespełna 300 tysięcy populacji Japończyków zamieszkujących kontynent i Hawaje. Był on też utrudniony z powodu oporu części Japończyków przed służbą w armii państwa, które zamknęło w obozach ich rodziny i stale poddawało w wątpliwość ich lojalność. Drugim czynnikiem przeszkadzającym w osiągnięciu pełnego stanu kadrowego była konieczność przekazywania żołnierzy, jako uzupełnień dla 100 Battalion walczącego we Włoszech. W ten sposób pułk utracił kilkaset osób, zarówno przed jak i po otrzymaniu rozkazu rozpoczęcia przygotowań do przeniesienia do Europy.

W rozdziale szóstym McCaffrey opisał kilkumiesięczny pobyt 442 RCT we Włoszech, kładąc nacisk na działania wojenne. Przybycie jednostki do Włoch, oznaczało zmianę dla 100 Battalion, który został włączony w skład pułku jako jego pierwszy batalion. Wywołało to niechęć ze strony żołnierzy batalionu, którzy walcząc przez osiem miesięcy, wyrobili sobie dobrą reputację, a jednocześnie czuli się mocno przywiązani do swojej jednostki. W rezultacie dowództwo poszło na pewne ustępstwo. 100 Battalion, pomimo że pozostał w składzie pułku, mógł zachować swoją nazwę.

Pierwsze dni po przyjeździe zapisały się w pamięci żołnierzy pozytywnie. Mieli oni możliwość m.in. zwiedzenia Rzymu, a przeszło $150 \mathrm{z}$ nich wzięło udział w audiencji u papieża Piusa XII. Nie obyło się jednak bez zgrzytów. Oddziały 522 Field Artillery Battalion były wizytowane przez dowódcę 34. dywizji piechoty, generała Charlesa Rydera. W trakcie pokazowych ćwiczeń, w wyniku błędu obsługi jednej z haubic, ostrzelany został teren, na którym znajdował się generał i towarzyszący mu oficerowie. Wywołało to u niego tak ogromny gniew, że rozkazat pułkownikowi Harrisonowi załadować swoich ludzi z powrotem na statki i zabrać do Stanów Zjednoczonych, do czasu, kiedy będq naprawde gotowi do walki (s. 189). Od końca czerwca do końca lipca Nisei brali udział w walkach w Toskanii, w okolicach Sassetty, Belvedere, Luciany i stolicy prowincji, 
Livorno. Spisali się w nich znakomicie, tylko 26 czerwca zabili 178 Niemców, wzięli do niewoli 86, ponadto zniszczyli m.in. 2 działa przeciwpancerne, 2 czołgi i 3 działa samobieżne. Za zasługi na polu walki, 27 lipca, 100 Battalion, został odznaczony przez dowódcę 5. Armii gen. Marka Clarka Distinguished Unit Citation. Podczas ceremonii generał wypowiedział słowa, będące dowodem uznania: Wy wszyscy Amerykanie japońskiego pochodzenia powinniście być dumni z siebie! 34 dywizja jest $z$ was dumna, 5 Armia jest $z$ was dumna,! Ameryka jest $z$ was dumna! (s. 219). Pomiędzy połową sierpnia a początkiem września 442 RCT walczył podzielony pomiędzy trzy różne jednostki, po ponownym połączeniu został przeniesiony z 5. Armii do 7. Armii walczącej we Francji.

Rozdział siódmy zawiera opis działań wojennych Nisei we Francji. Trwały one od momentu lądowania aliantów w południowej Francji (operacja „Dragoon") do połowy marca 1945 r. Główne siły 442 RCT, będące w składzie 36. dywizji, wkroczyły do walki w połowie października. Wyjątkiem była kompania antyczołgowa, która wzięła udział w inwazji w składzie oddziałów szybowcowych. Sytuacja ta była rezultatem braku dostępności takich jednostek w wojskach spadochronowych i szybowcowych biorących udział w desancie. W ramach przygotowania do operacji, żołnierze kompanii przeszli przyspieszone szkolenie szybowcowe. Okres najcięższych działań wojennych przypadł na październik, gdy bataliony piechoty pułku wzięły udział w walkach mających za cel wyrwanie z okrążenia niedaleko Biffontaine niespełna 300 żołnierzy z 1. batalionu 141. pułku 36. dywizji piechoty. Operacja zakończyła się sukcesem, 30 października 442 RCT przebił się do pozostających przy życiu 211 okrążonych żołnierzy. W walkach o uratowanie tzw. zaginionego batalionu poniósł bardzo duże straty. W całym październiku wyniosły one ok. 800 zabitych, rannych i zaginionych. W rezultacie u części żołnierzy powstało przekonanie, jak pisze McCaffrey, obecne także po wielu latach, że zostali użyci jako „mięso armatnie”. Przekonanie to mające za podstawę szacunki, często pojawiające się także w literaturze, według których ceną za uratowanie nieco ponad 200 żołnierzy, była utrata $800 \mathrm{Nisei}$, zostało przez autora uznane za błędne. Zgodne z jego oceną straty japońskich batalionów podczas walk o wyrwanie z okrążenia żołnierzy 141. pułku (26-30 października), wyniosły 37 zabitych i maksymalnie 410 rannych (s. 271-272).

Rozdział ósmy przedstawia losy 442 RCT w ostatnich tygodniach wojny. Pułk został przeniesiony z Francji do Włoch, gdzie ponownie znalazł się w składzie 5 Armii. Stoczył tam ostanie ciężkie walki okupione sporymi stratami. W bitwie o Mount Belvedere, na początku kwietnia, zginęło 19 żołnierzy, a 65 zostało rannych. Jednostka brała udział w walkach do momentu kapitulacji wojsk niemieckich we Włoszech 2 maja 1945 r. Inaczej potoczyły się losy 522 Field Artillery Battalion. Już wcześniej oddzielony od głównych sił 442 RTC, pozostał w Niemczech, ostatnie tygodnie wojny walcząc w składzie kilku rożnych dywizji. Artylerzyści stali się świadkami ogromu hitlerowskich zbrodni. Pod koniec kwietnia, tak jak i inni żołnierze amerykańscy, natrafili na niemieckie obozy 
koncentracyjne, wśród nich podobóz obozu w Dachau. To, co zobaczyli, wstrząsnęło nimi. Jak stwierdził McCaffrey, część z nich, zamieszkująca wcześniej kontynentalną część Stanów Zjednoczonych i mająca za sobą doświadczenie obozów internowania znalazła dodatkowy powód do zatrzymania się. Jeden z żołnierzy wspominał: kiedy zobaczytem baraki i ogrodzenia z drutu kolczastego, przypomniat mi się obóz Poston, z którego zgłosiłem się na ochotnika. To ironia, ze wielu z nas, pochodzacych z obozów przesiedlenia, przybyło do Niemiec pomóc Żydom. Skala i cel uwięzienia amerykańskich Japończyków i Żydów byty różne, ale powód byt ten sam: dyskryminacja rasowa (s. 318).

Ostatni rozdział przedstawia losy Nisei po zakończeniu działań wojennych w Europie. Był to dla nich trudny czas oczekiwania na powrót do domu. Pierwsi żołnierze opuścili Europę już pod koniec maja, ostatni, z 442. pułku dopiero w czerwcu 1946 r. Dokonania wojenne Nisei zostały zauważone przez prezydenta Harry'ego Trumana, który stwierdził: walczyliście nie tylko z wrogiem, ale także $z$ uprzedzeniami $-i$ zwyciężyliście (s. 339). Powojenne losy żołnierzy układały się różnie. Wyróżnia się postać Daniela Inouye, który reprezentował Hawaje w Kongresie jako senator przez pół wieku (1962-2012). Ani w ostatnim rozdziale książki, ani w epilogu nie ma niestety informacji statystycznych dotyczących liczebności oddziałów czy strat osobowych. Dane te, co prawda, częściowo pojawiają w poszczególnych rozdziałach, jednak całościowe podsumowanie byłoby przydatne. Podobnie brak informacji na temat liczby odznaczeń uzyskanych przez Nisei. Autor porusza ten temat w ostatnim rozdziale w kontekście odznaczeń uzyskanych przez Carla Morita, nie zaś całych oddziałów. Oddziały składające się z Nisei słynęły z waleczności i w rezultacie na ich koncie znajdowało się wiele odznaczeń. W przypadku 442 RCT było to: 7 Distinguished Unit Citation, 21 Medal of Honor, 29 Distinguished Service Crosses, 588 Silver Stars, ponad 4 tysiące Bronze Stars i ponad 4 tysiące Purple Hearts 9.

Książka Jamesa McCaffrey’a warta jest przeczytania. Dzieje oddziałów złożonych z Amerykanów pochodzenia japońskiego przedstawia w sposób interesujący, przystępny i dogłębny. Nie skupia się wyłącznie na przedstawieniu działań wojennych, ale umiejętnie włącza w treść wątki społeczne, np. stosunek Nisei do społeczeństw europejskich czy wobec dyskryminacji rasowe, istniejącej na południu Stanów Zjednoczonych. „Going for Broke” z pewnością jest pracą przydatną oraz wartościową zarówno dla historyka zawodowego, jak i pasjonata.

\section{Mariusz Puchacz}

Wydział Historyczno-Socjologiczny

Uniwersytet w Białymstoku

9 442nd Regimental Combat Team, autor hasła Franklin Odo, http://encyclopedia.densho.org/ 442nd_Regimental_Combat_Team/. 